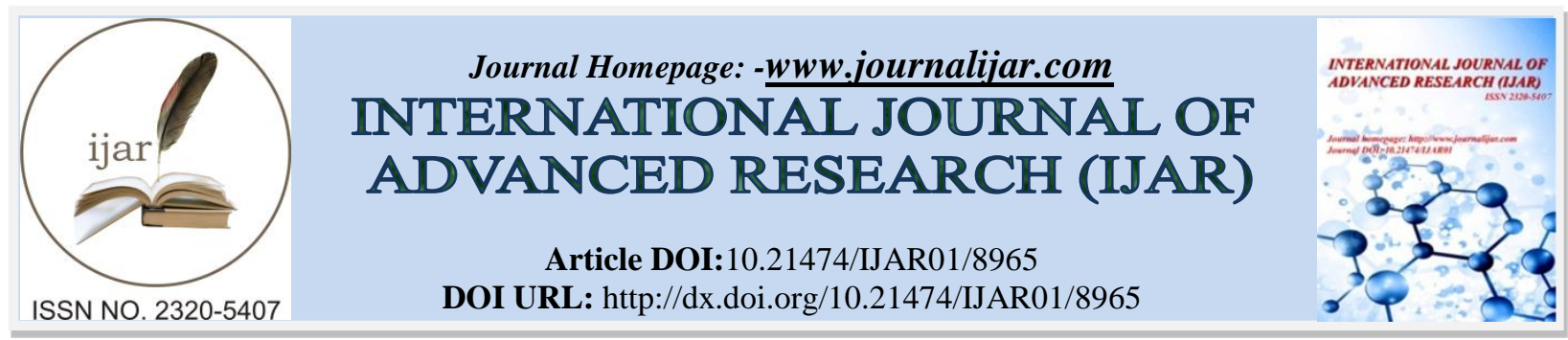

RESEARCH ARTICLE

\title{
THE EFFECT OF ORGANIZATIONAL JUSTICE AND WORK MOTIVATION ON AFECTIVE COMMITMENTS OF SCHOOL PRINCIPLE.
}

Iceu Rufiana, Sutjipto And Suparno Eko Widodo.

Doctoral Program of Educational Management, Universitas Negeri Jakarta, Jakarta, Indonesia.

\section{Manuscript Info}

Manuscript History

Received: 22 February 2019

Final Accepted: 24 March 2019

Published: April 2019

Key words:-

organizational justice, motivation, affective commitment.
Abstract

Principals are teachers who are given additional tasks to lead and manage schools in an effort to improve the quality of education. Therefore, a strong affective commitment from a school principal is needed. The purpose of this study was to examine the direct effect of organizational justice and work motivation on the affective commitment of the Principal of the High School. This research was conducted in DKI of Jakarta, Indonesia. This study uses a survey method with the path analysis approach. Data collection is by distributing questionnaires as many as 90 respondents with simple random sampling technique with Slovin formula. Based on the results of testing the hypothesis in this study it was concluded that there was a positive direct effect on organizational justice and work motivation that would increase the principal's affective commitment. This study presents implications for education administrators and policy makers in order to increase affective commitment through strengthening organizational justice and work motivation.

Copy Right, IJAR, 2019,. All rights reserved.

\section{Introduction:-}

Principals according to the Regulation of the Minister of National Education of the Republic of Indonesia No. 28 of 2010 are teachers who are given additional duties to lead and manage schools in an effort to improve the quality of education. Therefore, leadership characteristics of superior principals are needed. Leadership characteristics are critical factors that help create a sustainable school climate that will enhance both teacher and student productivity (Fook \& Sidhu, 2009, p. 114). One of the leadership characteristics that principals must have is affective commitment. Affective commitment is an emotional attachment between the principal and the organization.

In the span of 2015-2016 in DKI Jakarta, Indonesia has 7 principals who were disrespected disrespectfully in relation to the issue of commitment from the principal to their functions and duties as headmaster, including: (1) errors in budgeting for school spending, (2) leaving school during the National Examination, and (3) violations in the New Student Admission Service (PPDB).

The above problems require the importance of principals who have a strong commitment to advance the school they lead. The lowest demand from the principal's commitment is an affective commitment.

Corresponding Author:-Iceu Rufiana.

Address:-Doctoral Program of Educational Management, Universitas Negeri Jakarta, Jakarta, Indonesia. 
The several factors that influence the principal's affective commitment are organizational justice and work motivation. Collquit, Lepine, and Wesson's research $(2017$, p.185) explained that "people who experience higher levels of equity tend to feel higher levels of affective commitment". In Kinicki and Fugate (2016, p.57) said "the tree components of organizational justice have varying effect on workplace outcomes, listed here in rough of strongest to weakest. Distributive justice significant effect to all outcome (organizational commitment) and is mostly coequal with procedural justice in effect". Furthermore Robbin and Judge (2017, p. 121) also explained that "while procedural and interactional justice tend to affects an employee's organization commitment, trust in his or her manager, and intention to quit". It can be explained that organizational justice has a relationship with affective commitment, which both tend to help the organization achieve its goals.

Furthermore, other factors that influence affective commitment are work motivation. Collquit, et.al. (2017, p. 185) explained that "the relationship between motivation and organizational commitment seems straight forward. After all, the psychological and physical forms of withdrawal that characterize less committed employees are themselves evidence of low levels of motivation".

Two situational variables that influence task commitment are the formal reward system and the intrinsically motivating properties of the work itself. Member commitment to perform the task effectively will be greater if the organization has a reward system that provides attractive rewards contingent on performance (Yukl, 2010, p. 241). Affective commitment of the principal in carrying out the task will be better if an organization has a good reward system and high work motivation.

Organizational justice and work motivation have a strong influence on the affective commitment of an organization directly or indirectly. In organizational justice, work motivation, and affective commitment are common problems in every organization especially in educational institutions. Therefore, the study of the effect of organizational justice and work motivation on the affective commitment of the principals of State High School is important, as information to stakeholders in efforts to improve the quality of education.

\section{Affective Commitment}

Luthans (2011, p. 148) explained that affective commitment involves employees' feelings of obligation to stay with the organization because they should; it is the right thing to do. While Rae Andre (2008, p. 128) stated that affective commitment is feeling of obligation to remain with every one's company. Furthermore Gibson, Ivancevich, Donnelly, and Konopaske (2012, p. 7) explained affective commitment is a feeling of loyalty for the organization.

It can be concluded that affective commitment is emotional attachment between employees and organizations. as for the dimensions are 1) the desire to remain in the organization, 2) have emotional ties with the organization, 3) have confidence in the values and goals of the organization.

\section{Organizational Justice}

Justice according to Colquitt, et.al. (2017, p. 199), "justice reflects the perceived fairness of an authority's desicision maker". While the notion of organizational justice according to Kinicki and Fugate (2016, p. 158) adalah, "organizational justice reflects the extent to which people perceive that are treated fairly at work". Similar opinions expressed by Gibson et al. (2012, p. 148) "organizational justice is the degree to which individuals feel fairly treated within the organization for which they work.

Robbins and Judge (2017), organizational justice is concerned more broadly with how employees feel authorities and decision-makers- at work treat them. Greenberg (2010, p. 36) says that organizational justice is formed from 4 (four) types of justice, namely "distributive justice, procedural justice, interpersonal justice, and information justice".

From the expert opinion above, it can be synthesized that organizational justice is how employees feel treated fairly by the organization when making a decision regarding the organization. The justice dimension consists of: (1) feeling fair to the salary received, (2) feeling procedurally fair in the organization, (3) feeling treated fairly by the authorities, and (4) getting balanced information regarding organizational decisions.

\section{Work Motivation}

According to Colquitt, et.al. (2017, p.164), explain that "motivation is defined as a set of energetic forces that originates both within and outside an employee, initiates work related effort, and determines its direction, intensity, and persistence. Motivation is a critical consideration because job performance is largely a function of two factors: motivation and ability". Whereas according to Schermerhom, Hunt, and Osborn (2011, p.210) argue that "motivation 
refers to the individual forces that account for the direction, level, and persistence of a person's effort expended at work". Next is Robbins and Judge (2017, p.244) motivation as the processes that account for an individual's intensity, direction, and persistence of effort toward attaining a goal.

Work Motivation is a set of internal/external abilities/strengths, psychological strengths, and accompanied by the existing work characteristics of all employees so that employees can show definite, focused, have high perseverance and commitment.

\section{Methods:-}

This study uses a survey method approach with the approach of path analysis. Data collection in this study was conducted through a questionnaire. The affordable population is all Principals in the State High School with a total of 117 people. Samples were taken using simple random of sampling technique based on sample technique formula from Slovin. The number of samples obtained was 90 respondents $(n=90)$. The analysis unit is Principal of the DKI of Jakarta- Senior High School.

The constellation model between variables consists of 3 (three) variables, namely: exogenous variables are organizational justice $\left(\mathrm{X}_{1}\right)$, work motivation $\left(\mathrm{X}_{2}\right)$, and endogenous variables are affective commitment $(\mathrm{Y})$. The constellation of research problem models that shows the model of the relationship between exogenous variables (X) and endogenous variables $(\mathrm{Y})$ is presented in "Figure 1" as follows.

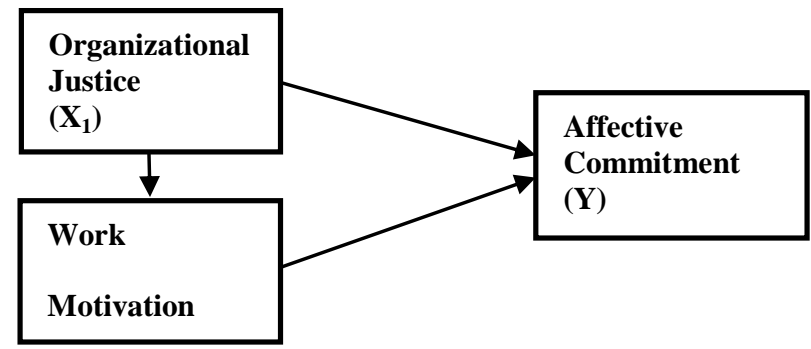

Figure 1:-Constellation Model of Research Problems.

Description:

Y

$\mathrm{X}_{1}$

$\mathrm{X}_{2}$

\section{: Affective Commitment \\ : Organizational Justice \\ : Work Motivation}

\section{Result And Discussion:- \\ Result}

Measurements are made on endogenous variables and exogenous variables. Exogenous variables are organizational justice $\left(\mathrm{X}_{1}\right)$, work motivation $\left(\mathrm{X}_{2}\right)$, and endogenous variables are affective commitment $(\mathrm{Y})$. Testing requirements analysis is done through normality test, linearity test, and regression significance test. The calculation results are presented in the following table.

Based on the results of the Liliefors statistical calculation on "Table 1", it is known that the normality for the estimation error between variables is $\mathrm{Y}$ above $\mathrm{X}_{1}, \mathrm{Y}$ above $\mathrm{X}_{2}$, and $\mathrm{X}_{1}$ above $\mathrm{X}_{2}$. Liliefors critical value $\mathrm{L}$-table for $\mathrm{n}=$ 90 at $\alpha=0,05$. From these results it is known that $\mathrm{L}_{\text {-count }} \leq \mathrm{L}$-table, so it can be concluded that the estimated distribution of errors between variables comes from populations that have a normal distribution.

Table 1:-Summary of Normality Test Results

\begin{tabular}{|l|l|l|l|l|l|l|}
\hline No & $\begin{array}{l}\text { Estimated Error } \\
\text { of Regression }\end{array}$ & & L-count & L-table & Description \\
\cline { 5 - 6 } & & & $\alpha=5 \%$ & $\alpha=1 \%$ & \\
\hline 2. & $Y$ above $\mathrm{X}_{1}$ & 90 & 0,0519 & 0,0934 & 0,109 & Normal \\
\hline 3. & $\mathrm{Y}_{2}$ above $\mathrm{X}_{2}$ & 90 & 0,0627 & 0,0934 & 0,109 & Normal \\
\hline
\end{tabular}


In order to draw conclusions in testing hypotheses, the regression models obtained are then tested for significance and linearity using the F-test in the ANAVA table. Test criteria for the significance and linearity of the regression model are set as follows:

Significant regression: $\mathrm{F}_{\text {- }}$ count $\geq \mathrm{F}_{\text {-table }}$ on the regression line

Linear regression: $\mathrm{F}_{-}$count $<\mathrm{F}_{\text {-table }}$ on the tuna line match.

The next step is to do a correlational analysis by reviewing the level and significance of the relationship between pairs of exogenous variables with endogenous variables. The conclusions are very significant regression or linear regression, the researchers present in "Table 2 ".

Table 2:-Summary of Significance Test Results and Linearity Regression

\begin{tabular}{|c|c|c|c|c|c|c|}
\hline \multirow[t]{3}{*}{$\operatorname{Reg}$} & \multirow[t]{3}{*}{ Equation } & \multicolumn{2}{|c|}{ Regression Test } & \multicolumn{2}{|c|}{ Linearity Test } & \multirow[t]{3}{*}{ Conclusion } \\
\hline & & \multirow[t]{2}{*}{$\mathrm{F}_{\text {count }}$} & $\mathrm{F}_{\text {table }}$ & \multirow[t]{2}{*}{$F_{\text {count }}$} & \multirow{2}{*}{\begin{tabular}{|l|}
$F_{\text {table }}$ \\
$\alpha=0,05$ \\
\end{tabular}} & \\
\hline & & & $\alpha=0,01$ & & & \\
\hline Y above $\mathrm{X}_{1}$ & $\begin{array}{l}\hat{\mathrm{Y}}=71,475+ \\
0,720 \mathrm{X}_{1}\end{array}$ & 48,72 & $6,93 * *$ & 1,238 & $1,65^{\mathrm{ns}}$ & Regression is very significant/Linear regression \\
\hline $\mathrm{Y}$ above $\mathrm{X}_{2}$ & $\begin{array}{l}\widehat{Y}=88,194+ \\
0,541 X_{2}\end{array}$ & 37,31 & $6,93 * *$ & 0,741 & $1,64^{\mathrm{ns}}$ & Regression is very significant/Linear regression \\
\hline $\mathrm{X}_{2}$ above $\mathrm{X}_{1}$ & $\begin{array}{l}X_{2}=63,464+ \\
0,625 X_{1}\end{array}$ & 31,49 & $6,93 * *$ & 0,688 & $1,65^{\mathrm{ns}}$ & Regression is verysignificant/Linear regression \\
\hline
\end{tabular}

The amount of direct influence and significance test for each path (Path Analysis) are summarized in the following table.

Table 3:-Summary of Path Significance of Test Results

\begin{tabular}{|l|l|l|l|l|l|l|}
\hline No. & Direct Influence & $\begin{array}{l}\text { Coefficient } \\
\text { Path }\end{array}$ & $\mathrm{dk}$ & $\mathrm{T}_{\text {count }}$ & $\mathrm{t}_{\text {table }}$ & \multicolumn{2}{l|}{} \\
\cline { 5 - 8 } & & 0,289 & 86 & 2,76 & $\alpha=0,05$ & $\alpha=0,01$ \\
\hline 2. & $\mathrm{X}_{1}$ to $\mathrm{Y}$ & 0,234 & 86 & 2,42 & 1,99 & 2,63 \\
\hline 3. & $\mathrm{X}_{2}$ to $\mathrm{Y}$ & $\mathrm{X}_{1}$ to $\mathrm{X}_{2}$ & 87 & 2,37 & 1,99 & 2,63 \\
\hline
\end{tabular}

Structurally the overall diagram of the path of each structure can be seen in Figure 2 below:

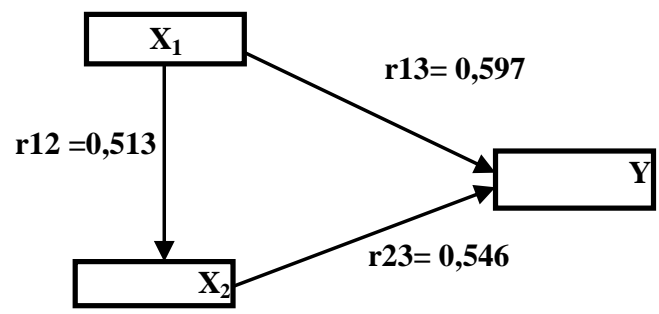

Figure 2:-Causal Path Diagram Effects of $\mathrm{X}_{1}$ and $\mathrm{X}_{2}$ on $\mathrm{Y}$.

Based on the path analysis test mentioned above, it can be explained that hypothesis testing is as follows:

First Hypothesis:

there is a positive direct effect on Organizational Justice $\left(\mathrm{X}_{1}\right)$ on Affective Commitments (Y).

The statistical hypothesis tested was a positive direct effect on Organizational Justice $\left(\mathrm{X}_{1}\right)$ on Affective Commitments (Y).

\section{Statistical hypothesis:}

$\mathrm{H} 0: \beta \mathrm{y} 2 \leq 0$

H1: $\beta \mathrm{y} 2>0$

Based on the results of the path analysis of the influence of Organizational Justice $\left(\mathrm{X}_{1}\right)$ against Affective Commitment (Y) obtained path coefficient $\rho y 1$ is 0,289 with $\mathrm{t}_{\text {count }}=2,76$, while the value $\mathrm{t}_{\text {table }}=1,99(\alpha=0,05 ; d k=$ 86). Therefore $t_{\text {count }}>t_{\text {table }}$, so $H_{0}$ is rejected, $H_{1}$ is accepted. Thus it can be concluded that Organizational Justice has a direct positive effect on Affective Commitments. 


\section{Second Hypothesis:}

there is a positive direct effect of Work Motivation $\left(\mathrm{X}_{2}\right)$ against Affective Commitments (Y).

The statistical hypothesis tested is a positive direct effect on Work Motivation $\left(\mathrm{X}_{2}\right)$ on Affective Commitment $(\mathrm{Y})$.

\section{Statistical hypothesis:}

$\mathrm{H} 0: \beta \mathrm{y} 3 \leq 0$

$\mathrm{H} 1: \beta \mathrm{y} 3>0$

Based on the results of the path analysis of the influence of Work Motivation $\left(\mathrm{X}_{2}\right)$ against Affective Commitments (Y) path coefficient obtained $\rho y 2$ is 0,234 , with $\mathrm{t}_{\text {-count }}=2,42$, while the score $\mathrm{t}_{\text {-table }}=1,99(\alpha=0,05 ; d k=86)$. Therefore $\mathrm{t}_{\text {-count }}>\mathrm{t}_{\text {-table }}$, so $\mathrm{H}_{0}$ is rejected, $\mathrm{H}_{1}$ is accepted. Thus it can be concluded that Work Motivation has a positive direct effect on Affective Commitment.

\section{Third hypothesis:}

there is a positive direct effect of Organizational Justice $\left(\mathrm{X}_{1}\right)$ towards Work Motivation $\left(\mathrm{X}_{2}\right)$.

The statistical hypothesis tested is a direct positive effect on Organizational Justice $\left(\mathrm{X}_{1}\right)$ towards Work Motivation $\left(\mathrm{X}_{2}\right)$.

\section{Statistical hypothesis:}

$\mathrm{H} 0: \beta 32 \leq 0$

$\mathrm{H} 1: \beta 32>0$

Based on the results of the analysis of the influence path of Organizational Justice $\left(\mathrm{X}_{1}\right)$ towards job motivation $\left(\mathrm{X}_{2}\right)$ path coefficient obtained $\rho 21$ is 0,267 with $\mathrm{t}_{\text {- }}{ }_{\text {cont }}=2,37$, while the score of $\mathrm{t}_{\text {table }}=1,99(\alpha=0,05 ; \mathrm{dk}=87)$. Therefore $\mathrm{t}$ count $>t_{\text {table }}$, so $\mathrm{H}_{0}$ is rejected, $\mathrm{H}_{1}$ is accepted. Thus it can be concluded that Organizational Justice has a positive direct effect on Work Motivation.

\section{Discussion:-}

Based on the results of analysis and hypothesis testing indicate that the three hypotheses proposed in this study are generally proven that each path has a positive direct effect. In detail, the discussion of the analysis and testing of the research hypothesis is described as follows:

\section{Organizational Justice Directly Affects Positive Affective Commitment}

The results of hypothesis testing indicate that Organizational Justice has a significant influence on Affective Commitments. The correlation coefficient value is 0.597 and the path coefficient value is 0.289 . This means that Organizational Justice has a significant positive influence on Affective Commitments.

The results of this study are in line with the opinions of several experts including Collquit, et.al. (2017, pp. 185), stated that "people who experience higher levels of equity tend to feel higher levels of affective commitment". Furthermore Kinicki and Fugate (2016, p.57) argue that "the tree components of organizational justice have varying effect on workplace outcomes, listed here in rough of strongest to weakest. Distributive justice significant effect to all outcome (organizational commitment) and is mostly coequal with procedural justice in effect".

Shane and Glinow (2015, p. 109) stated that "affective commitment is higher in organizations that fulfil their obligation to employees and abide by humanitarian values, such as fairness, courtesy, forgiveness, and moral integrity. These value related to concept of organizational justice". Meanwhile Robbins and Judge (2017, p. 121) argue that "while procedural and interactional justice tend to affects an employee's organization commitment, trust in his or her manager, and intention to quit".

\section{Work Motivation Directly Influences Positive Affective Commitments}

The results of hypothesis testing indicate that Work Motivation has a significant influence on Affective Commitments. The correlation coefficient value is 0.546 and the path coefficient value is 0.234 . This means that Work Motivation has a significant positive influence on Affective Commitments.

The results of this study are in line with the opinions of several experts including Collquit, et.al. (2017, p. 185), stated that: 
The relationship between motivation and organizational commitment seems straight forward. After all, the psychological and physical forms of withdrawal that characterize less committed employees are themselves evidence of low levels of motivation. Clearly employees who are daydreaming, coming in late, and taking longer breaks are struggling to put forth consistently high level of work effort. Research on equity and organizational commitment offers the clearest insights into the motivation - commitment relationship. Specifically, employees who feel a sense of equity are more emotionally attached to their firms and feel a stronger sense of obligation to remain.

Gibson et.al. (2012, p. 183) explained that "there's limited research on the relationship between rewards and organizational commitment. Commitment to an organization involves three attitudes: (1) a sense of identification with the organization's goals, (2) a feeling of involvement in organizational duties, and (3) a feeling of loyalty for the organization. Research evidence indicates that the absence of commitment can reduce organizational effectiveness. Intrinsic rewards are important for developing organizational commitment Organizations able to meet employees' needs by providing challenging opportunities, giving feedback, encouraging employee participation and by recognizing achievement when it occurs have a significant impact on commitment. Thus, managers need to develop intrinsic reward systems that focus on personal importance or self-esteem to integrate individual and organizational goals and to design challenging jobs".

While Griffin and Gregory (2014, p.74) stated that "organizations can do few definitive things to promote satisfaction and commitment, but some specific guidelines are available. For one thing, if the organization treats its employees fairly and provides reasonable rewards and job security, its employees are more likely to be satisfied and committed". Commitment will result from efforts to exercise power if the leader in this case is the principal who treats employees fairly and always motivates the student. For example, a leader is able to explain a new device that will benefit the organization if it is developed. A person who is committed will work hard to complete his work, even if it has to work overtime. This simple method generally becomes the big role of a leader in school.

\section{Organizational Justice Directly Influences Positive Work Motivation}

The results of hypothesis testing indicate that Organizational Justice has a significant influence on Work Motivation. The correlation coefficient value is 0.513 and the path coefficient value is 0.267 . This means that Organizational Justice has a significant positive influence on Work Motivation.

The results of this study are in line with the opinion of Collquit, et.al. (2017, p. 156) that "equity theory is a model of motivation that explains how people strive for fairness and justice in social exchanges or give and take relationships". Next Champoux, Joseph E. (2017, p. 164) stated that "an analysis of rights and justice would question employees' rights to know in advance that their managers will try to shape their behavior with knowledge of human motivation. A manager working from ethical egoism would say it is right for him to have that effect, because it meets his interests in his work unit's performance and his career".

As for Gibson et.al. (2012, p. 173) explain that "procedural justice has been shown to have a positive impact on a number of affective and behavioural reactions at the workplace. 72 In other words, when employees perceive high levels of procedural justice with the organization's resource and allocation decisions, they are more likely to be intrinsically motivated".

The statement above explains that Justice is a positive reaction that encourages motivation in the workplace. Positive feelings and awards given in the workplace fairly in every important decision making in the organization will greatly affect motivation in employees.

\section{Conclusions And Implication:- \\ Conclusions}

Based on the results of the analysis and discussion of the research, the conclusions in this study are as follows:

1. There is a significant positive direct effect of organizational justice on affective commitment, which means that good organizational justice will increase the principal's normative commitment, and vice versa the worse the organizational justice will be followed by low affective commitment.

2. There is a significant positive direct effect of work motivation on affective commitment, which means a high level of work motivation will increase the principal's affective commitment, and vice versa the lower the level of work motivation will be followed by the principal's affective commitment. 
3. There is a significant positive direct effect of organizational justice on work motivation, which means that the better organizational justice, the work motivation of the principal will increase, and opposite, the worse the organizational justice will be followed by low work motivation.

\section{Implication}

1. Efforts to Increase Affective Commitment Through Strengthening Organizational Justice

2. Based on the results of this study, it can be stated that to achieve affective commitment of school principals can be done by strengthening organizational justice, including namely manners, forgiveness, and moral integrity. The steps of the school organization to improve the organizational justice of the principal can be done by giving the school principal the opportunity to get equal treatment and get equal opportunities in terms of information and career path enhancement

3. Efforts to Increase Affective Commitment Through Strengthening Work Motivation

4. Based on the results of this study, it can be stated that the achievement of affective commitment is to increase the principal's confidence in himself to complete the tasks and responsibilities of work carried out, with indicators of responsibility, work effort, and perseverance in work, so that problems are faced, and overcome work situation can be resolved.

5. In increasing affective commitment through work motivation is to involve the role of the principal optimally in various activities in the school, so that the experience experienced by the principal can improve his ability to solve problems. Another way to improve the ability of the principal is to do a comparative study in another school, so that the principal sees a picture of his ability, thus, when the principal is confident in his abilities, it will affect the principal's affective commitment.

\section{References:-}

1. Andre, Rae. (2008). Organizational Behavior An Introduction to Your Life in Organizations. New Jersey: Pearson Prentice Hall.

2. Champoux, Joseph E. (2017). Organizational Behaviour. New York: Taylor \& Francis.

3. Colquitt, Jason A., Lepine, Jeffrey A., and Wesson, Michael J., (2017). Organizational Behavior: Improving Performance and Commitment in the Workplace Third Edition. New York: McGraw-Hill.

4. Fook, Chan Yuen \& Sidhu, Gurnam Kaur. (2009). Leadership Characteristics of An Excellent Principal in Malaysia. International Education Studies, 2 (4), 106-116.

5. Gibson, James L., Ivancevich, John M., Donnely, James H., Jr., \& Konopaske, Robert. (2012). Organization Behavior, Structure, Processes. New York: Mc GrawHill Companies, Inc.

6. Griffin, Ricky W., \& Gregory, Moorhead. (2014). Organizational Behavior Managing People and Organizations. South - Western: Congage Learning.

7. Kinicky, Angelo \& Fugate, Mel. (2016). Organizational Behavior a Pratical, Problem Solving Approach. New York : McGrawHill Companies, Inc.

8. Locke, Edwin A., (2009). Handbook of Principles of Organizational Behavior, West Sussex. John Wiley and Sons Ltd.

9. Luthans, Fred. (2011). Organizational Behavior An Evidence-Based Approach. New York: McGraw-Hill Education, Inc.

10. Randall, S. Peterson, \& Mannix, Elizabeth A. (2008). Leading and Managing People in the Dynamic Organization Lawrence Erlbaum Associates. Publishers Mahwah, New Jersey, London.

11. Robbins, Stephen, P., \& Judge, Timothy. (2017). Organizational Behavior. New Jersey: Pearson Education Inc.

12. Schermerhorn, Jhon R., Jr, Hunt, James G., Osbor, Richard N., \& Bien, Mary Uhl. (2011). Organizational Behavior. New York: Jhon Wiley \& Sons Inc.

13. Shane, Steven L. Mc \& Glinow, Mary Ann Von. (2015). Organizational Behavior Emerging Knowledge and Practice for the Real World. New York: Mc Graw Hill.

14. Yukl, Gary. (2010). Leadership in Organizations. New Jersey: Pearson Education, Inc. 